Provided for non-commercial research and education use. Not for reproduction, distribution or commercial use.

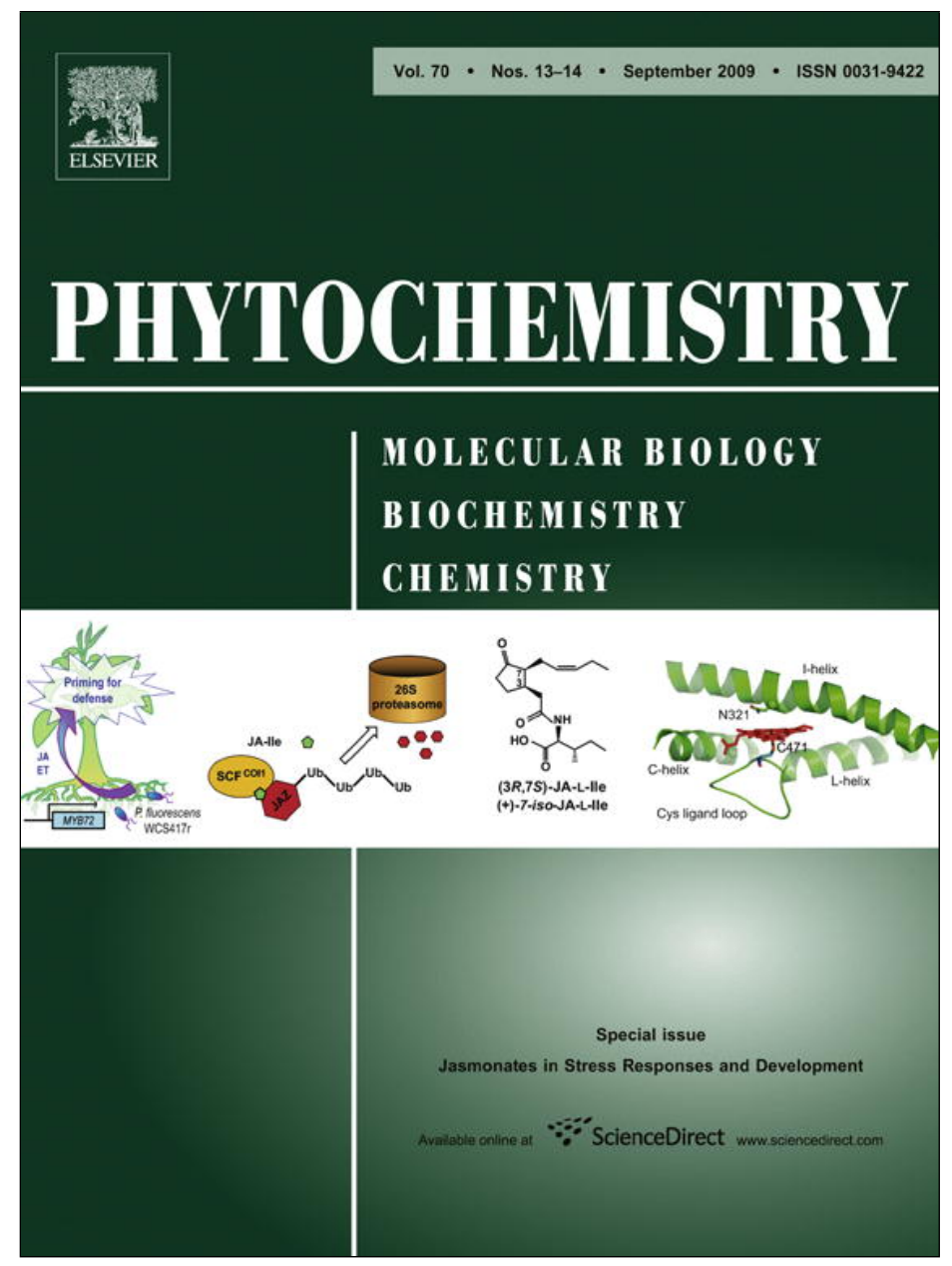

This article appeared in a journal published by Elsevier. The attached copy is furnished to the author for internal non-commercial research and education use, including for instruction at the authors institution and sharing with colleagues.

Other uses, including reproduction and distribution, or selling or licensing copies, or posting to personal, institutional or third party websites are prohibited.

In most cases authors are permitted to post their version of the article (e.g. in Word or Tex form) to their personal website or institutional repository. Authors requiring further information regarding Elsevier's archiving and manuscript policies are encouraged to visit:

http://www.elsevier.com/copyright 
Review

\title{
Jasmonate signaling in plant interactions with resistance-inducing beneficial microbes
}

\author{
Sjoerd Van der Ent ${ }^{\mathrm{a}, \mathrm{b}}$, Saskia C.M. Van Wees ${ }^{\mathrm{a}}$, Corné M.J. Pieterse $\mathrm{a}^{\mathrm{a}, \mathrm{b}, *}$ \\ ${ }^{a}$ Plant-Microbe Interactions, Institute of Environmental Biology, Faculty of Science, Utrecht University, P.O. Box 800.56, 3508 TB Utrecht, The Netherlands \\ ${ }^{\mathrm{b}}$ Centre for Biosystems Genomics, P.O. Box 98, 6700 AB Wageningen, The Netherlands
}

\section{A R T I C L E I N F O}

\section{Article history:}

Received 27 March 2009

Received in revised form 5 June 2009

Available online 25 August 2009

\section{Keywords:}

Beneficial microorganisms

Plant growth-promoting rhizobacteria

(PGPR) and fungi (PGPF)

Induced systemic resistance (ISR)

Defense signaling

Ethylene

Jasmonic acid

Microbe-associated molecular patterns

(MAMPs)

Priming

Transcription factors

\begin{abstract}
A B S T R A C T
Beneficial soil-borne microorganisms can induce an enhanced defensive capacity in above-ground plant parts that provides protection against a broad spectrum of microbial pathogens and even insect herbivores. The phytohormones jasmonic acid (JA) and ethylene emerged as important regulators of this induced systemic resistance (ISR). ISR triggered by plant growth-promoting rhizobacteria and fungi is often not associated with enhanced biosynthesis of these hormones, nor with massive changes in defense-related gene expression. Instead, ISR-expressing plants are primed for enhanced defense. Priming is characterized by a faster and stronger expression of cellular defense responses that become activated only upon pathogen or insect attack, resulting in an enhanced level of resistance to the invader encountered. Recent advances in induced defense signaling research revealed regulators of ISR and suggest a model in which (JA)-related transcription factors play a central role in establishing the primed state.
\end{abstract}

(c) 2009 Elsevier Ltd. All rights reserved.

\section{Contents}

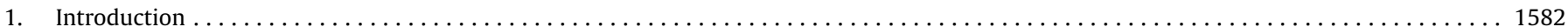



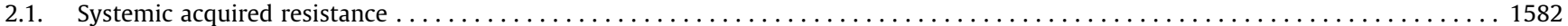



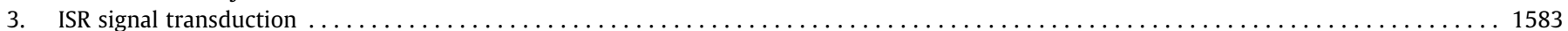

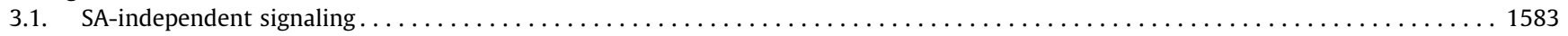

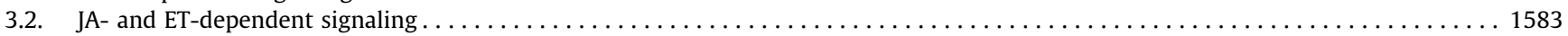

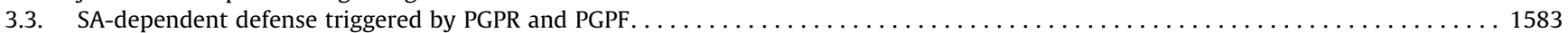

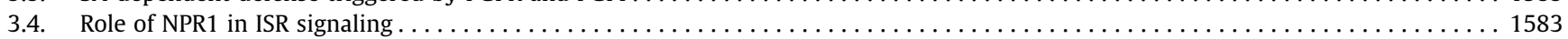

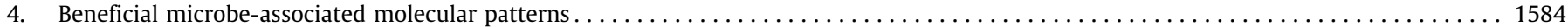

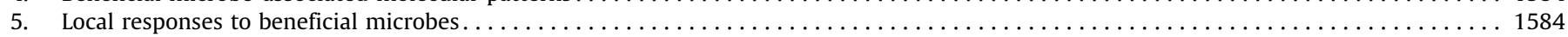

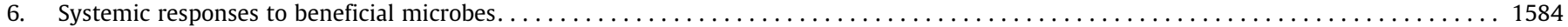

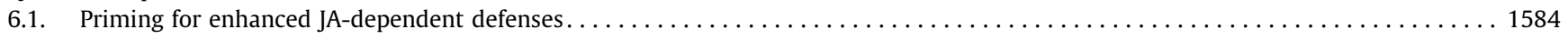



Abbreviations: BTH, benzothiadiazole; ET, ethylene; ETI, effector triggered immunity; ISR, induced systemic resistance; JA, jasmonic acid; LPS, lipopolysaccharides; MAMPs, microbe-associated molecular patterns; MAPKs, mitogen activated protein kinases; PAMPs, pathogen associated molecular patterns; PGPR, plant growth-promoting rhizobacteria; PGPF, plant growth-promoting fungi; PR, pathogenesis related; PTI, PAMP-triggered immunity; RT-PCR, real-time reverse transcriptase polymerase chain reaction; SA, salicylic acid; SAR, systemic acquired resistance; VOCs, volatile organic compounds.

* Corresponding author. Address: Plant-Microbe Interactions, Institute of Environmental Biology, Faculty of Science, Utrecht University, P.O. Box 800.56, 3508 TB Utrecht, The Netherlands. Tel.: +3130253 6887; fax: +31302532837.

E-mail address: C.M.J.Pieterse@uu.nl (C.M.J. Pieterse). 


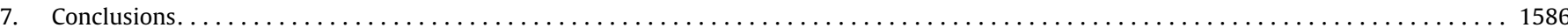

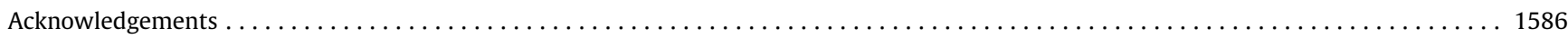

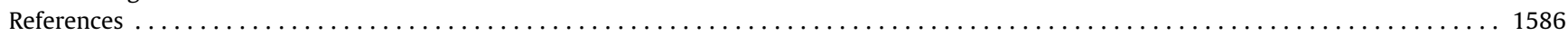

\section{Introduction}

Plant roots are surrounded by a nutrient-rich habitat, called the rhizosphere, which provides a niche to a large and diverse community of microorganisms that thrive on root exudates (Lugtenberg et al., 2001; Walker et al., 2003). Within this community of competing and interacting microbes, a whole range of parasitic and beneficial microorganisms can be found that either cause disease or enhance plant performance, respectively. Mycorrhizal fungi and Rhizobium spp. are amongst the best-studied beneficial microorganisms. Mycorrhizal fungi provide the host with an enhanced root surface to absorb water and mineral nutrients such as phosphate (Harrison, 2005; see review by Hause and Schaarschmidt in this issue), whereas Rhizobium spp. fix nitrogen from the atmosphere into ammonium which can be used for amino acid biosynthesis (Spaink, 2000; see review by Hause and Schaarschmidt in this issue). Plant growth-promoting rhizobacteria (PGPR) and fungi (PGPF) are another class of soil-borne microbes with beneficial effects on plant performance. PGPR and PGPF are non-pathogenic and occur in large numbers in the rhizosphere. They can stimulate plant growth by enhancing the plant's photosynthetic capacity (Zhang et al., 2008), by increasing tolerance to abiotic stress (Yang et al., 2009), or by suppressing plant diseases (Harman et al., 2004; Kloepper et al., 2004; Pozo and Azcon-Aguilar, 2007; Van Loon et al., 1998) and insect herbivory (Van Oosten et al., 2008; Zehnder et al., 2001). The disease suppressive activity of PGPR and PGPF is exerted either directly by hampering growth and development of soil-borne pathogens through competition for nutrients or secretion of antibiotics in the rhizosphere (Bakker et al., 2007; De Bruijn et al., 2007; Debode et al., 2007; Handelsman and Stabb, 1996; Kamilova et al., 2008), or indirectly by eliciting a plant-mediated systemic resistance response (Kloepper et al., 2004; Van Loon et al., 1998; Van Wees et al., 2008). Systemic resistance triggered by beneficial microorganisms confers a broad-spectrum resistance that is effective against different types attackers. The phytohormone jasmonic acid and its derivatives, collectively called jasmonates (JAs), emerged as important regulators of this systemic immune response. Here, we review our current understanding of the signaling pathways that control the immune responses that are triggered by beneficial microbes, with special emphasis on the regulatory role of JAs in this process.

\section{Systemically induced disease resistance}

\subsection{Systemic acquired resistance}

In the 1960s, Ross demonstrated that limited primary infection with a pathogen rendered non-infected plant tissues more resistant to subsequent pathogen attack. This long-lasting and broadspectrum induced disease resistance is referred to as systemic acquired resistance (SAR; Durrant and Dong, 2004; Ross, 1961). The onset of SAR is associated with increased levels of salicylic acid (SA), and is characterized by the coordinate activation of a specific set of PATHOGENESIS-RELATED (PR) genes, many of which encode PR proteins with antimicrobial activity (Van Loon et al., 2006). Studies with transgenic and mutant plants that are impaired in the production or perception of SA demonstrated a central role for this phytohormone in SAR (Loake and Grant, 2007; Vlot et al., 2008). The regulatory protein NPR1 (NONEXPRESSOR OF PR GENES1) emerged as an important transducer of the SA signal, which upon activation by SA acts as a transcriptional co-activator of $P R$ gene expression (Dong, 2004). Besides SA, other hormones are implicated in SAR signaling as well. In tobacco, Verberne et al. (2003) demonstrated that ethylene (ET) perception is required for the onset of SA-dependent SAR that is triggered upon infection by tobacco mosaic virus. In addition, Truman et al. (2007) showed that the JA-signaling mutants sgt1b (suppressor of g2 allele of SKP1 1b), opr3 (12-oxo-phytodienoate reductase 3) and jin1 (jasmonate insensitive 1) failed to develop SAR upon leaf infiltration with an avirulent strain of the pathogen Pseudomonas syringae pv. tomato, suggesting that JAs play a role in SAR as well. However, other JA-signaling mutants such as jar1 (jasmonate resistant 1), eds8 (enhanced disease susceptibility 8), and coi1 (coronatine insensitive 1) were shown to develop normal levels of SAR (Attaran et al., 2009; Cui et al., 2005; Pieterse et al., 1998; Ton et al., 2002a). Hence, the exact role of JA signaling in SAR needs to be further explored.

\subsection{Induced systemic resistance}

Besides pathogens, also non-pathogenic microbes can elevate the level of disease resistance in plants. This was first evidenced by experiments in which colonization of plant roots by PGPR were shown to protect above-ground plant tissues against different types of pathogens (Van Loon et al., 1998). Like pathogen-induced SAR, this PGPR-mediated induced systemic resistance (ISR) has been demonstrated in many plant species and has a broad-spectrum of effectiveness (Kloepper et al., 2004; Van Loon and Bakker, 2006; Van Loon et al., 1998; Van Wees et al., 2008). Among the ISRinducing PGPR documented to date are many non-pathogenic Pseudomonas spp. and Bacillus spp. (Kloepper et al., 2004; Van Loon and Bakker, 2006). Although both SAR and ISR are effective against different types of pathogens, their range of effectiveness is partly divergent. For instance, in Arabidopsis thaliana it was shown that SAR triggered by an avirulent strain of the bacterial leaf pathogen P. syringae pv. tomato and ISR elicited by the PGPR Pseudomonas fluorescens WCS417r (WCS417r) are similarly effective against diseases caused by virulent $P$. syringae, the fungal root pathogen Fusarium oxysporum, and the downy mildew pathogen Hyaloperonospora arabidopsidis (Pieterse et al., 1996; Ton et al., 2002b). However, SAR was shown to be effective against turnip crinckle virus, whereas ISR was not (Ton et al., 2002b). Conversely, ISR was shown to protect Arabidopsis against the necrotrophic pathogens Alternaria brassicicola (Ton et al., 2002b), Botrytis cinerea (Van der Ent et al., 2008) and Plectosphaerella cucumerina (Segarra et al., 2009), whereas SAR was ineffective against these pathogens. Over the last decade it has become clear that, like PGPR, many PGPF are able to trigger a similar broad-spectrum ISR. Amongst the documented ISR-inducing PGPF are mycorrhizal fungi (Pozo and Azcon-Aguilar, 2007) and non-pathogenic strains of $F$. oxysporum (Duijff et al., 1998; Paparu et al., 2007), Trichoderma spp. (Vinale et al., 2008), Penicillium sp. GP16-2 (Hossain et al., 2008), Pythium oligandrum (Hase et al., 2008), Piriformospora indica (Waller et al., 2005) and related Sebacinales spp. (Waller et al., 2008). 


\section{ISR signal transduction}

\subsection{SA-independent signaling}

Although SAR and ISR are phenotypically similar in that they both confer a broad-spectrum disease resistance in systemic plant parts, they are regulated by different signal transduction pathways. First evidence for the differential regulation of SAR and ISR came from studies with the PGPR WCS417r. In radish, WCS417rISR was shown to be effective against Fusarium wilt disease, but the enhanced resistance was not associated with the accumulation of PR proteins that are characteristic for SAR (Hoffland et al., 1995). In accordance, transcriptional activity of $P R$-genes was not increased in systemic leaf tissue of Arabidopsis upon induction of ISR by WCS417r (Pieterse et al., 1996). Furthermore, treatment of the roots of Arabidopsis with WCS417r was not associated with an increase in SA levels in systemic ISR-expressing leaf tissues (Pieterse et al., 2000). Moreover, transgenic Arabidopsis NahG plants that are unable to accumulate SA due to ectopic expression of the bacterial salicylate hydroxylase gene $n a h G$, showed a similar level of induced disease resistance upon colonization of the roots by WCS417 $r$ as did wildtype plants, indicating that WCS417r-ISR functions independently of SA (Pieterse et al., 1996). Since then, many examples of SA-independent ISR have been demonstrated in Arabidopsis (Ahn et al., 2007; Iavicoli et al., 2003; Ryu et al., 2003; Segarra et al., 2009; Stein et al., 2008; Van Wees et al., 1997) and other plant species, such as tobacco (Press et al., 1997; Zhang et al., 2002), cucumber (Press et al., 1997), tomato (Hase et al., 2008; Tran et al., 2007; Yan et al., 2002), and rice (De Vleesschauwer et al., 2008). Hence, the ability to activate an SA-independent pathway controlling systemic disease resistance seems to be common for beneficial microorganisms and occurs in a broad range of plant species against different types of attackers.

\subsection{JA- and ET-dependent signaling}

In the past decade, research on the defense signaling pathways that are activated by beneficial microorganisms revealed that JA and ET are central players in the regulation of ISR. In Arabidopsis, WCS417r-ISR was shown to be blocked in the JA-signaling mutants jar1, jin1, eds8, and coi1 (Pieterse et al., 1998; Pozo et al., 2008; Ton et al., 2002a), and in ET signaling mutants such as etr1 (ethylene response 1) and ein2 (ethylene insensitive 2) (Knoester et al., 1999; Pieterse et al., 1998). Also for other PGPR the role of JAs and ET in the regulation of the ISR response of Arabidopsis has been established (Ahn et al., 2007; Iavicoli et al., 2003; Ryu et al., 2004b). Likewise, ISR triggered by the PGPF Penicillium sp. GP16-2, Trichoderma harzianum T39 and P. indica was shown to be blocked in JAand ET-signaling mutants of Arabidopsis (Hossain et al., 2008; Korolev et al., 2008; Stein et al., 2008).

Also in other plant species, evidence is accumulating for a role of JAs and ET in the regulation of ISR. For instance, in tomato the JA-insensitive mutant def1 (defenseless 1) and the ET-insensitive mutant $\mathrm{Nr}$ (Never ripe) were not capable of mounting ISR against the oomycete pathogen Phytophthora infestans upon colonization of the roots by the PGPR Bacillus pumilus SE34 or P. fluorescens 89 B61 (Yan et al., 2002). Similarly, colonization of the roots of wildtype and nahG-expressing tomato plants by the non-pathogenic oomycete $P$. oligandrum resulted in a decrease in Ralstonia solanacearum-inflicted disease symptoms, whereas the ISR response was blocked in mutant jai1 (jasmonic acid insensitive 1) plants (Hase et al., 2008). In addition, using nahG-expressing rice, an ET-insensitive OsEIN2 antisense rice line, and the JA-deficient rice mutant hebiba, De Vleesschauwer et al. (2008) demonstrated that the ability of $P$. fluorescens WCS374r to trigger ISR against the rice leaf blast pathogen Magnaporthe oryzae is regulated by an SA-independent but JA/ET-modulated signaling pathway. In cucumber, application of the chemical inhibitors silver thiosulfate and diethyldithiocarbamate, which block the action of ET and the synthesis of JA, respectively, reduced Trichoderma asperellum T203-mediated ISR against $P$. syringae pv. lachrymans, indicating a role for JA/ET-dependent signaling in ISR in this plant species (Shoresh et al., 2005). Hence, the picture is emerging that JAs and ET are the dominant hormonal players in the regulation of the SA-independent plant immune response that is triggered by beneficial microorganisms.

\subsection{SA-dependent defense triggered by PGPR and PGPF}

Although the majority of studies on beneficial microbe-induced resistance point to a role for JAs and ET in the regulation of the induced immune response (Van Loon and Bakker, 2006), several examples of PGPR and PGPF that trigger the SA-dependent SAR response have been documented as well. For instance, a SA-producing mutant of the PGPR Pseudomonas aeruginosa 7NSK2 was shown to induce resistance in wildtype tobacco but not in SA-degrading NahG tobacco (De Meyer et al., 1999). Similarly, the PGPR Paenibacillus alvei K165 was shown to induce systemic resistance against Verticillium dahliae in Arabidopsis, but this was blocked in the SAbiosynthesis mutants eds5 (enhanced disease susceptibility 5) and sid2 (salicylic acid induction deficient 2) (Tjamos et al., 2005). Furthermore, Bacillus subtilis FB17-induced resistance in Arabidopsis against $P$. syringae pv. tomato was shown to be associated with an increase in SA levels and enhanced $P R-1$ expression (Rudrappa et al., 2008). Also, resistance induced by the Gram-positive bacterium Streptomyces sp. strain EN27 against Erwinia carotovora and F. oxysporum in Arabidopsis was shown to be associated with SA signaling (Conn et al., 2008).

\subsection{Role of NPR1 in ISR signaling}

The defense regulatory protein NPR1 plays a key role in SAdependent SAR, but has also been implicated in JA/ET-dependent ISR (Dong, 2004; Pieterse and Van Loon, 2004). For instance, mutant Arabidopsis npr1 plants were shown to be blocked in their ability to express ISR upon colonization of the roots by the PGPR WCS417r (Pieterse et al., 1998), P. fluorescens CHAO (Iavicoli et al., 2003), P. fluorescens 89B61 (Ryu et al., 2003), Pseudomonas putida LSW17S (Ahn et al., 2007), Serratia marcescens 90-166 (Ryu et al., 2003) and B. pumilus SE34 (Ryu et al., 2003), and the PGPF Penicillium sp. GP16-2 (Hossain et al., 2008), P. indica (Stein et al., 2008) and T. asperellum T34 (Segarra et al., 2009). In SAR, NPR1 plays an important role as transcriptional co-activator of SA-responsive $P R$ gene expression. However, SA-independent ISR is not accompanied by the activation of SA-responsive $P R$-genes (Pieterse et al., 1996). Hence, the role of NPR1 in ISR must be different from that in SAR. These different roles of NPR1 are not mutually exclusive, because simultaneous activation of SAR and ISR can lead to an additively enhanced defensive capacity compared to that of SAR and ISR (Van Wees et al., 2000). This suggests that NPR1 is important in regulating and connecting different hormone-dependent induced defense pathways (Dong, 2004; Pieterse and Van Loon, 2004; Pieterse et al., 2009). While the role of NPR1 in SA-signaling is clearly connected to a function of this regulatory protein in the nucleus (Dong, 2004), evidence is accumulating that the role of NPR1 in JA/ET signaling is connected to a cytosolic function of NPR1 (Leon-Reyes et al., 2009; Stein et al., 2008). However, the exact molecular mechanisms by which NPR1 exerts its role in these JA/ET-dependent ISR remains to be elucidated. 


\section{Beneficial microbe-associated molecular patterns}

Induction of a plant-mediated ISR response starts with the recognition of the beneficial microorganism. It is well documented that pathogenic and beneficial microorganisms are specifically recognized by the plant through conserved microbial cell surface components, such as flagellin and lipopolysaccharides (LPS). Collectively these general determinants are referred to as pathogenor microbe-associated molecular patterns (PAMPs or MAMPs, respectively; Schwessinger and Zipfel, 2008). Interaction of a PAMP with the corresponding pattern recognition receptor of the plant activates a primary defense response that is called PAMP-triggered immunity (PTI; Jones and Dangl, 2006; Schwessinger and Zipfel, 2008). In analogy to PAMPs, a diversity of MAMPs of beneficial microorganisms have been implicated in the onset of ISR (Bakker et al., 2007; Kloepper et al., 2004; Van Loon et al., 2008; Van Wees et al., 2008). So far, MAMPs produced by PGPF have only been identified for Trichoderma spp. (Vinale et al., 2008). For instance the hydrophobin-like elicitor Sm1 of Trichoderma virens Gv29-8 was shown to function as an ISR-mediating MAMP in both maize (Zea mays) and cotton (Gossypium hirsutum) (Djonović et al., 2007). Both the monocot and the dicot plant species generated enhanced levels of resistance against Colletotrichum graminicola upon treatment with $\mathrm{Sm} 1$. Moreover, $\mathrm{Sm} 1$ was demonstrated to be required for $T$. virens Gv29-8 mediated ISR in maize (Djonović et al., 2007). In contrast to wildtype $T$. virens Gv29-8, a Sm1 deletion strain of this PGPF did not protect maize plants against $C$. graminicola, while overexpression of $\mathrm{Sm} 1$ enhanced the resistance-inducing capacity of this strain. For PGPR, many more MAMPs have been identified, including flagellin and LPS, but also secreted bacterial components, such as $\mathrm{Fe}^{3+}$-chelating siderophores, antibiotics, biosurfactants, and even volatile organic compounds (VOCs) were shown to elicit ISR (Bakker et al., 2007; Iavicoli et al., 2003; Raaijmakers et al., 2006; Ryu et al., 2004a; Weller et al., 2002). Often, bacterial mutants lacking one of these MAMPs are still able to trigger ISR (Bakker et al., 2007; Meziane et al., 2005), indicating that plants can recognize multiple MAMPs produced by the same strain. This redundancy in the ability of PGPR-derived MAMPs to induce resistance is also common to pathogen-derived PAMPs (Bittel and Robatzek, 2007), and is thought to guarantee robustness of the induced immune response.

\section{Local responses to beneficial microbes}

To understand how recognition of a soil-borne beneficial microorganism is translated into a systemic defense response, a limited number of studies investigated the metabolic or transcriptional changes in the roots upon colonization. In the roots of rice and tomato plants, mycorrhizal fungi were shown to induce the accumulation of a number of transcripts and proteins, respectively, many of which with a predicted function in plant defense (Güimil et al., 2005; Pozo and Azcon-Aguilar, 2007). Likewise, a proteome approach of rice roots colonized by endophytic $\mathrm{N}_{2}$-fixing Azoarcus spp. identified an increase in JA-regulated PR-, salt stress-relatedand putative receptor like-proteins, especially in less-compatible interactions (Miché et al., 2006). In Medicago truncatula the initial local transcriptional responses to the mycorrhizal fungus Glomus mosseae showed significant overlap to those initiated by the PGPR P. fluorescens C7R12 (Sanchez et al., 2005). Moreover, both beneficials were unable to elicit these shared transcriptional responses in the symbiosis-defective mutant dmi3 (does not make infections 3 ), suggesting that the signaling pathways that are triggered by these different beneficials converge (Sanchez et al., 2005). Similarly, the Arabidopsis ISR pathways triggered by the PGPR WCS417r and the PGPF T. asperellum T34 were shown to converge upstream of
MYB72, an early key component in the onset of ISR (Segarra et al., 2009; Van der Ent et al., 2008). MYB72 is a transcription factor gene that was identified in a microarray-based search for rootspecific, PGPR-responsive genes (Van der Ent et al., 2008; Verhagen et al., 2004; Fig. 1A). Analysis of myb72 mutant plants revealed that MYB72 is required for the onset of WCS417r- and T. asperellum T34-mediated ISR against a set of (hemi)biotrophic and necrotrophic pathogens (Segarra et al., 2009; Van der Ent et al., 2008), again indicating that the ISR pathways triggered by very different beneficial microbes converge.

\section{Systemic responses to beneficial microbes}

\subsection{Priming for enhanced JA-dependent defenses}

The role of JAs and ET in the regulation of PGPR- and PGPF-triggered systemic defense responses has been mainly established through the analysis of JA- and ET-signaling mutants. However, colonization of the roots by ISR-inducing PGPR is often not associated with an increase in the production of these hormones (Pieterse et al., 2000). Hence, ISR seems to be based on increased sensitivity rather than on increased production of these hormones. Supportive of this notion is the observation that colonization of the roots by beneficial microorganisms is generally not associated with direct activation of JA/ET-responsive genes. As a matter of fact, the transcriptional changes that occur in systemic tissues upon colonization of the roots by beneficial microbes is in general relatively weak, especially in comparison to the massive transcriptional reprogramming that occurs upon pathogen attack (Fu et al., 2007; Liu et al., 2007; Verhagen et al., 2004; Wang et al., 2005). However, upon pathogen or insect attack, ISR-expressing plants display an accelerated defense response (Van Wees et al., 2008; Verhagen et al., 2004). This PGPR-mediated sensitization of the tissue for enhanced defense expression is called 'priming' and is characterized by a faster and/or stronger activation of cellular defenses upon pathogen or insect attack resulting in enhanced resistance to the invader encountered (Conrath et al., 2006; Frost et al., 2008).

A

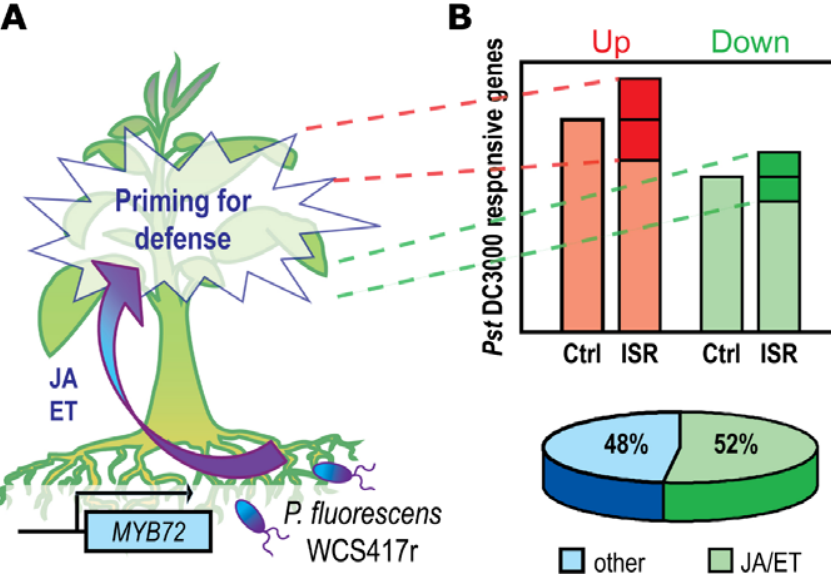

Fig. 1. WCS417r-ISR in Arabidopsis is associated with priming for enhanced JAregulated defenses. (A) Colonization of the roots of Arabidopsis by the PGPR Pseudomonas fluorescens WCS417r triggers an ISR response that is effective against a broad range of pathogens and against specific insects (Ton et al., 2002b; Van Oosten et al., 2008). Systemic activation of ISR requires activation of the transcription factor gene MYB72 in the roots (Van der Ent et al., 2008) and an intact response to the plant hormones JA and ET (Pieterse et al., 1998). (B) WCS417 $r$ does not trigger direct changes in defense-related gene-expression in above-ground plant parts, but primes the leaf tissue for a faster and stronger response to pathogen and insect attack (Van Oosten et al., 2008; Van Wees et al., 1999; Verhagen et al., 2004). The set of WCS417r-primed genes, represented by the dark parts of the ISR bars, is enriched for JA- and/or ET-responsive genes (Verhagen et al., 2004). 
Examples of priming during ISR come from transcriptome analyses of Arabidopsis plants of which the roots were treated with the PGPR P. putida LSW17S (Ahn et al., 2007), or with Bradyrhizobium sp. strain ORS278 (Cartieaux et al., 2008). These studies uncovered a large number of JA/ET-regulated genes that showed a primed expression pattern after pathogen infection. Also, the JA/ET-dependent resistance that is triggered by the PGPF T. asperellum T203 in cucumber is associated with augmented $P R$-gene expression after pathogen infection (Shoresh et al., 2005). Likewise, colonization of Arabidopsis roots by the PGPF T. asperellum T34 (Segarra et al., 2009) or Penicillium sp. strain GP16-2 (Hossain et al., 2008) primed JA-responsive genes for enhanced expression upon pathogen attack. Analysis of the transcriptome of WCS417r-ISR revealed that the majority of the 81 Arabidopsis genes that were primed for enhanced expression upon infection by $P$. syringae were regulated by JA and/or ET (Verhagen et al., 2004; Fig. 1A and B), confirming earlier observations that the JA- and/or ET-responsive genes VSP2 (VEGATIVE STORAGE PROTEIN 2), PDF1.2 (PLANT DEFENSIN 1.2), and HEL (HEVEIN LIKE) were primed during WCS417r-ISR (Hase et al., 2003; Van Wees et al., 1999). Interestingly, Arabidopsis leaves expressing WCS417r-ISR also displayed potentiated expression of PDF1.2 and HEL upon feeding by the generalist insect herbivore Spodoptera exigua (beet armyworm), but not when the leaves were damaged by the specialist herbivore Pieris rapae (small cabbage white) (Van Oosten et al., 2008). Accordingly, colonization of Arabidopsis roots by WCS417r reduced growth and development of $S$. exigua but not that of $P$. rapae, indicating that priming for enhanced defense-related gene expression is associated with enhanced resistance. Although priming for enhanced JA/ET-dependent defenses is well documented, it should be noted that priming for JA/ET-independent defenses by PGPR and PGPF has also been reported (Conn et al., 2008; Pozo and Azcon-Aguilar, 2007; Tjamos et al., 2005; Waller et al., 2005; Van der Ent et al., 2009).

\subsection{Molecular mechanisms of priming for enhanced JA-dependent defenses}

Priming provides the plant with an enhanced capacity for rapid and effective activation of cellular defense responses to effectively combat pathogen or insect attack. However, the molecular mechanisms underlying priming are still poorly understood. Hypothetically, the primed state is based on the accumulation, or posttranslational modification of one or more signaling proteins that, after being expressed and/or modified, still remain inactive. Upon perception of a pathogen- or insect-derived stress signal this enhanced defense signaling capacity would enable a faster and stronger defense reaction. Since priming is clearly expressed at the transcriptional level, transcription factor proteins are likely candidates for being actors in this two-step regulatory mechanism.

To identify transcription factors involved in the regulation of priming, Pozo et al. (2008) followed a whole-genome transcript

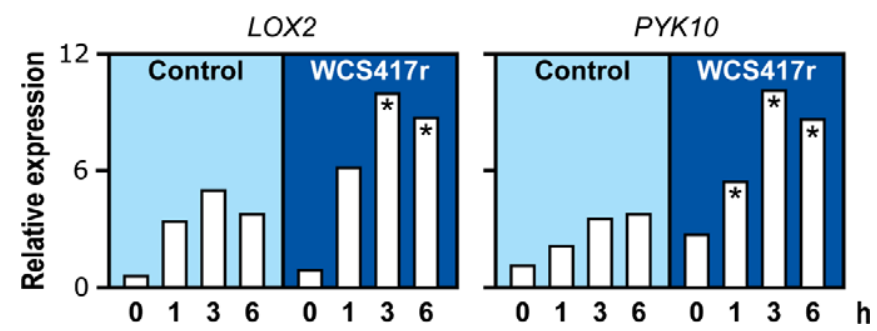

Fig. 2. Potentiated expression of JA-responsive defense-related genes. LOX2 and PYK10 are examples of ISR-primed, MeJA-responsive genes that show a potentiated MeJA-induced expression pattern in WCS417r-ISR-expressing plants (Pozo et al., 2008). profiling approach to identify the set of JA-responsive genes that are primed upon induction of WCS417r-ISR. To this end, uninduced and WCS417r-ISR-expressing plants were treated with MeJA after which ISR-primed, JA-responsive genes such as LOX2 (LIPOXYGENASE 2) and PYK10 (encoding a $\beta$-glucosidase; Fig. 2 ) were selected. Interestingly, the set of ISR-primed genes was enriched for JAresponsive genes that were previously identified as being responsive to the JA-inducing pathogens and insects $P$. syringae, $A$. brassicicola, $P$. rapae, and Frankliniella occidentalis (Western flower thrips) (De Vos et al., 2005). This suggests that JA-responsive genes that are activated by JA-inducing attackers are selectively primed during ISR (Fig. 3). In silico analysis of the promoters of 442 ISRprimed, JA-responsive genes revealed that the primed genes were significantly enriched for a cis-acting G-box-like motif in comparison to non-primed, JA-responsive genes (Fig. 4A). This promoter element can serve as a binding site for the basic helix-loop-helix leucine zipper transcription factor MYC2 (originally called JIN1 for JASMONATE INSENSITIVE1), which plays a central role in JAand abscisic acid-regulated signaling (Lorenzo and Solano, 2005). MYC2-impaired jin1 mutants were unable to mount WCS417rISR against $P$. syringae and $H$. arabidopsidis (Pozo et al., 2008; Fig. 4B) or P. indica-mediated ISR against Golovinomyces orontii (Stein et al., 2008), pinpointing MYC2 as an important regulator in priming during ISR.

In another approach to identify transcription factors involved in priming, Van der Ent et al. (2009) analyzed the expression profile
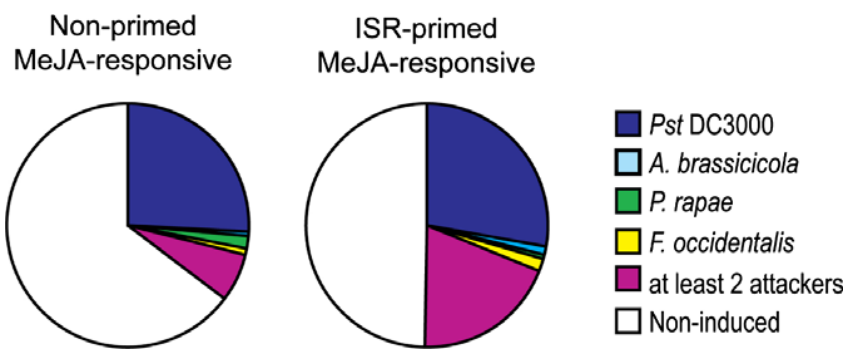

Fig. 3. ISR-primed JA-responsive genes are enriched for defense-related genes. The set of ISR-primed genes is enriched for JA-responsive genes that were previously identified as responsive to the JA-inducing pathogens Pseudomonas syringae pv. tomato DC3000 (Pst DC3000) and Alternaria brassicicola, and the insect herbivores Pieris rapae and Frankliniella occidentalis (De Vos et al., 2005; Pozo et al., 2008), suggesting that JA-responsive genes that are activated by JA-inducing attackers are selectively primed during ISR.
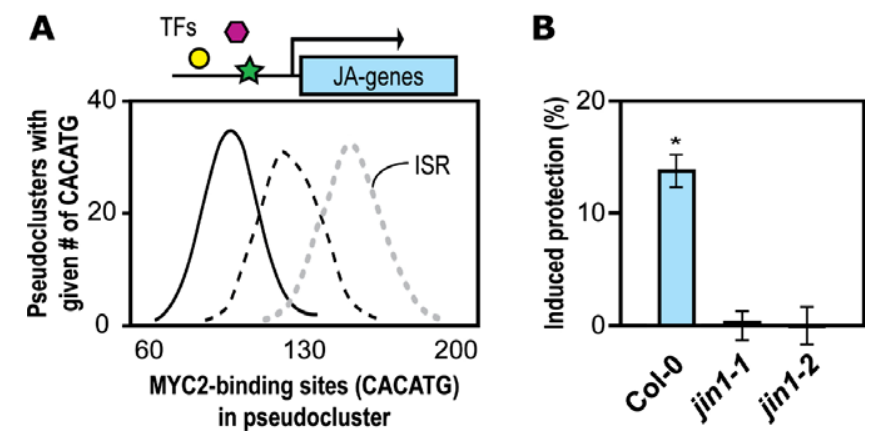

Fig. 4. The transcription factor MYC2 is required for WCS417r-mediated ISR. (A) In silico analysis of the promoter regions of MeJA-responsive genes demonstrated that the cis-acting G-box-like motif CACATG, which serves as a docking site for the transcription factor MYC2, was significantly overrepresented in ISR-primed, MeJAresponsive genes (grey dashed lines) when compared to unprimed, MeJA-responsive genes (black dashed lines), and randomly selected promoters from the Arabidopsis genome (solid black lines) (Pozo et al., 2008). (B) WCS417r-mediated protection against Pst DC3000, as observed in wildtype Arabidopsis Col-0 plants, is lost in MYC2-impaired mutants jin1-1 and jin1-2 (Pozo et al., 2008). 

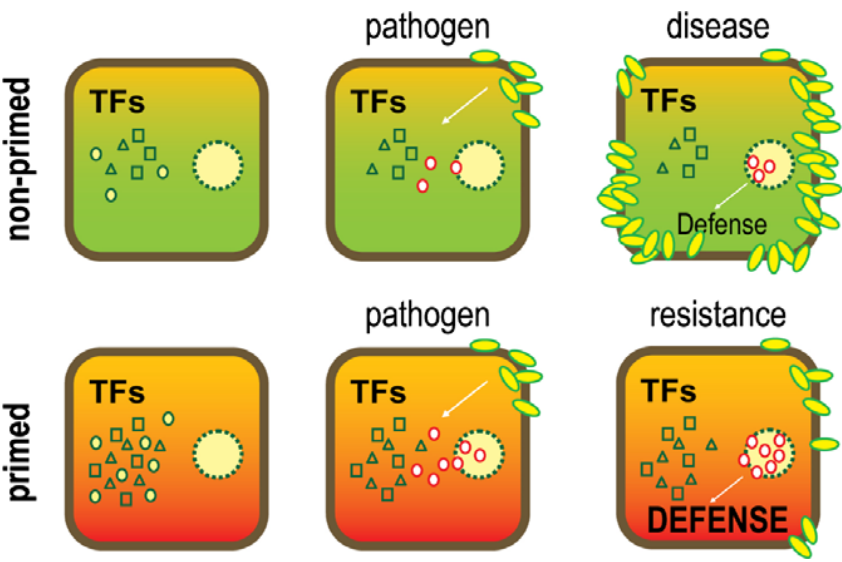

Fig. 5. Model for the role of transcription factors in priming for enhanced defense. Whole-genome expression profiling of transcription factor genes revealed a large number of transcription factor genes that are activated upon colonization of the roots by WCS417r (Van der Ent et al., 2009). This may lead to the accumulation of a pool of inactive transcription factors (TFs) in the cytosol (left panel). In response to a secondary stress stimulus, such as infection by a pathogen, specific TFs are activated (middle panel). Since the primed cells of WCS417r-treated plants contain a larger pool of latent TFs, cellular defense responses can be activated faster and stronger, resulting in an enhanced level of resistance when compared to the non-primed plants (courtesy of Dr. Jurriaan Ton).

of over 2000 potential Arabidopsis transcription factor genes upon induction of the primed state by WCS417r using a robotized realtime reverse transcription (RT)-PCR-based resource for quantitative measurement of transcripts (Czechowski et al., 2004). In the absence of a pathogen, colonization of the roots by WCS417r caused a consistent change in the expression in the leaves of more than 100 transcription factor genes, amongst which MYC2 (Van der Ent et al., 2009). In an earlier, microarray-based study these transcription factor genes were not identified (Verhagen et al., 2004), most likely because this latter technique is substantially less sensitive than the RT-PCR based tool (Czechowski et al., 2004). Different types of transcription factor genes were induced, but the AP2/ERF (APETALA2/ETHYLENE-RESPONSIVE FACTORS) family of transcription factors was notably overrepresented. Several members of the AP2/ERF family have been implicated in the regulation of JA- and ET-dependent defenses (Lorenzo et al., 2003; Pré et al., 2008). However, their exact role in the regulation of the priming response during ISR remains to be elucidated.

Although WCS417r directly induced the expression of several transcription factor genes, such as $M Y C 2$, no significant downstream activation of defense-related genes was observed in the absence of a pathogen (Verhagen et al., 2004). This suggests that the transcription factors remain inactive until the perception of a secondary pathogen- or insect-derived signal (Fig. 5). Hence, regulatory mechanisms that act post-translationally are likely to be involved in priming as well. Recently, the inactive forms of the mitogen activated protein kinases (MAPKs) MPK3 and MPK6 were found to accumulate upon priming induced by the SA-analogue benzothiadiazole (BTH) (Beckers et al., 2009). These signaling components only became activated upon treatment with a secondary stress, suggesting a role for MAPKs in priming. Epigenetic regulation of gene expression has been suggested to play a role in priming as well (Bruce et al., 2007). However, future research is required to fully understand the molecular mechanisms underlying the priming phenomenon.

\section{Conclusions}

Research on plant immune responses that are triggered by beneficial microorganisms is rapidly expanding. In recent years, many examples of beneficial microorganisms that are able to induce resistance against pathogens and pests have been described. From this research, the picture is emerging that the response of plants to beneficial microbes is regulated via JA- and ET-dependent signaling pathways. Often, the induced resistance is not accompanied by massive changes in defense-related gene expression. Instead, beneficials seem to be exceptionally well capable of priming plants for enhanced defense. Priming for enhanced defense is a common feature of induced resistance and can explain the broad-spectrum effectiveness that is typical for many induced resistance phenomena (Conrath et al., 2006; Frost et al., 2008). Since plant defenses are costly and involve diversion of resources away from plant growth and development (Heil and Baldwin, 2002; Walters and Heil, 2007), priming for enhanced defense is generally considered to be a cost-effective defense mechanism (Pieterse and Dicke, 2007; Walters and Boyle, 2005). Through the study of the costs and benefits of priming in Arabidopsis, it was shown that the fitness costs of priming are indeed lower than those of constitutively activated defenses (Van Hulten et al., 2006). Moreover, the fitness benefit of priming was shown to outweigh its costs under pathogen pressure. Recent findings on priming for enhanced defense in barley (Hordeum vulgare) are in good agreement with these results (Walters et al., 2009). Saccharin-mediated priming for augmented defense expression had no significant effect on plant growth rate and grain yield in the absence of pathogen infection. However, under high disease pressure by the hemibiotrophic fungus Rhynchosporium secalis, significant increases in these parameters were observed for plants that had been primed. Hence, priming for enhanced defense, such as triggered by beneficial microorganisms may be a valuable tool for sustainable crop protection.

\section{Acknowledgements}

The authors of this review are supported by VICI Grant No. 865.04.002 of the Earth and Life Sciences Foundation, which is subsidized by the Netherlands Organization of Scientific Research (NWO); the Centre for BioSystems Genomics (CBSG), which is part of the Netherlands Genomics Initiative of NWO; and project T3103 of the Top Institute Pharma.

\section{References}

Ahn, I.-P., Lee, S.-W., Suh, S.-C., 2007. Rhizobacteria-induced priming in Arabidopsis is dependent on ethylene, jasmonic acid, and NPR1. Mol. Plant-Microbe Interact. 20, 759-768.

Attaran, E., Zeier, T.E., Griebel, T., Zeier, J., 2009. Systemic acquired resistance in Arabidopsis is independent of methyl salicylate production and jasmonate signaling. Plant Cell 21, 954-971.

Bakker, P.A.H.M., Pieterse, C.M.J., Loon, L.C.V., 2007. Induced systemic resistance by fluorescent Pseudomonas spp. Phytopathology 97, 239-243.

Beckers, G.J.M., Jaskiewicz, M., Liu, Y., Underwood, W.R., He, S.Y., Zhang, S., Conrath, U., 2009. Mitogen-activated protein kinases 3 and 6 are required for full priming of stress responses in Arabidopsis thaliana. Plant Cell 21, 944-953.

Bittel, P., Robatzek, S., 2007. Microbe-associated molecular patterns (MAMPs) probe plant immunity. Curr. Opin. Plant Biol. 10, 335-341.

Bruce, T.J.A., Matthes, M.C., Napier, J.A., Pickett, J.A., 2007. Stressful "memories" of plants: evidence and possible mechanisms. Plant Sci. 173, 603-608.

Cartieaux, F., Contesto, C., Gallou, A., Desbrosses, G., Kopka, J., Taconnat, L., Renou, J.P., Touraine, B., 2008. Simultaneous interaction of Arabidopsis thaliana with Bradyrhizobium sp. strain ORS278 and Pseudomonas syriugae pv. tomato DC3000 leads to complex transcriptome changes. Mol. Plant-Microbe Interact. 21, 244259.

Conn, V.M., Walker, A.R., Franco, C.M.M., 2008. Endophytic actinobacteria induce defense pathways in Arabidopsis thaliana. Mol. Plant-Microbe Interact. 21, 208 218.

Conrath, U., Beckers, G.J.M., Flors, V., García-Agustín, P., Jakab, G., Mauch, F., Newman, M.-A., Pieterse, C.M.J., Poinssot, B., Pozo, M.J., Pugin, A., Schaffrath, U., Ton, J., Wendehenne, W., Zimmerli, L., Mauch-Mani, B., 2006. Priming: getting ready for battle. Mol. Plant-Microbe Interact. 19, 1062-1071

Cui, J., Bahrami, A.K., Pringle, E.G., Hernandez-Guzman, G., Bender, C.L., Pierce, N.E., Ausubel, F.M., 2005. Pseudomonas syringae manipulates systemic plant defenses against pathogens and herbivores. Proc. Natl. Acad. Sci. USA 102, 1791-1796. 
Czechowski, T., Bari, R.P., Stitt, M., Scheible, W.R., Udvardi, M.K., 2004. Real-time RTPCR profiling of over 1400 Arabidopsis transcription factors: unprecedented sensitivity reveals novel root- and shoot-specific genes. Plant J. 38, 366-379.

De Bruijn, I., De Kock, M.J.D., Yang, M., De Waard, P., Van Beek, T.A., Raaijmakers, J.M., 2007. Genome-based discovery, structure prediction and functional analysis of cyclic lipopeptide antibiotics in Pseudomonas species. Mol. Microbiol. 63, 417-428.

De Meyer, G., Audenaert, K., Höfte, M., 1999. Pseudomonas aeruginosa 7NSK2induced systemic resistance in tobacco depends on in planta salicylic acid accumulation but is not associated with PR1a expression. Eur. J. Plant Pathol. $105,513-517$.

De Vleesschauwer, D., Djavaheri, M., Bakker, P.A.H.M., Höfte, M., 2008. Pseudomonas fluorescens WCS374r-induced systemic resistance in rice against Magnaporthe oryzae is based on pseudobactin-mediated priming for a salicylic acidrepressible multifaceted defense response. Plant Physiol. 148, 1996-2012.

De Vos, M., Van Oosten, V.R., Van Poecke, R.M.P., Van Pelt, J.A., Pozo, M.J., Mueller, M.J., Buchala, A.J., Métraux, J.P., Van Loon, L.C., Dicke, M., Pieterse, C.M.J., 2005. Signal signature and transcriptome changes of Arabidopsis during pathogen and insect attack. Mol. Plant-Microbe Interact. 18, 923-937.

Debode, J., Maeyer, K.D., Perneel, M., Pannecoucque, J., Backer, G.D., Hofte, M., 2007. Biosurfactants are involved in the biological control of Verticillium microsclerotia by Pseudomonas spp.. J. Appl. Microbiol. 103, 1184-1196.

Djonović, S., Vargas, W.A., Kolomiets, M.V., Horndeski, M., Wiest, A., Kenerley, C.M., 2007. A proteinaceous elicitor Sm1 from the beneficial fungus Trichoderma virens is required for induced systemic resistance in maize. Plant Physiol. 145 $875-889$.

Dong, X., 2004. NPR1, all things considered. Curr. Opin. Plant Biol. 7, 547-552.

Duijff, B.J., Pouhair, D., Olivain, C., Alabouvette, C., Lemanceau, P., 1998. Implication of systemic induced resistance in the suppression of fusarium wilt of tomato by Pseudomonas fluorescens WCS417r and by nonpathogenic Fusarium oxysporum Fo47. Eur. J. Plant Pathol. 104, 903-910.

Durrant, W.E., Dong, X., 2004. Systemic acquired resistance. Annu. Rev. Phytopathol. $42,185-209$

Frost, C.J., Mescher, M.C., Carlson, J.E., De Moraes, C.M., 2008. Plant defense priming against herbivores: getting ready for a different battle. Plant Physiol. 146, 818824.

Fu, Z.Q., Guo, M., Jeong, B.R., Tian, F., Elthon, T.E., Cerny, R.L., Staiger, D., Alfano, J.R., 2007. A type III effector ADP-ribosylates RNA-binding proteins and quells plant immunity. Nature 447, U281-U284.

Güimil, S., Chang, H.S., Zhu, T., Sesma, A., Osbourn, A., Roux, C., Ionnidis, V., Oakeley, E.J., Docquier, M., Descombes, P., Briggs, S.P., Paszkowski, U., 2005. Comparative transcriptomics of rice reveals an ancient pattern of response to microbial colonization. Proc. Natl. Acad. Sci. USA 102, 8066-8070.

Handelsman, J., Stabb, E.V., 1996. Biocontrol of soilborne plant pathogens. Plant Cell 8, 1855-1869.

Harman, G.E., Howell, C.R., Viterbo, A., Chet, I., Lorito, M., 2004. Trichoderma speciesopportunistic, avirulent plant symbionts. Nat. Rev. Microbiol. 2, 43-56.

Harrison, M.J., 2005. Signaling in the arbuscular mycorrhizal symbiosis. Annu. Rev. Microbiol. 59, 19-42.

Hase, S., Takahashi, S., Takenaka, S., Nakaho, K., Arie, T., Seo, S., Ohashi, Y., Takahashi, $\mathrm{H}$., 2008. Involvement of jasmonic acid signalling in bacterial wilt disease resistance induced by biocontrol agent Pythium oligandrum in tomato. Plant Pathol. 57, 870-876.

Hase, S., Van Pelt, J.A., Van Loon, L.C., Pieterse, C.M.J., 2003. Colonization of Arabidopsis roots by Pseudomonas fluorescens primes the plant to produce higher levels of ethylene upon pathogen infection. Physiol. Mol. Plant Pathol. 62, 219226

Heil, M., Baldwin, I.T., 2002. Fitness costs of induced resistance: emerging experimental support for a slippery concept. Trends Plant Sci. 7, 61-67.

Hoffland, E., Pieterse, C.M.J., Bik, L., Van Pelt, J.A., 1995. Induced systemic resistance in radish is not associated with accumulation of pathogenesis-related proteins. Physiol. Mol. Plant Pathol. 46, 309-320.

Hossain, M.M., Sultana, F., Kubota, M., Hyakumachi, M., 2008. Differential inducible defense mechanisms against bacterial speck pathogen in Arabidopsis thaliana by plant-growth-promoting-fungus Penicillium sp. GP16-2 and its cell free filtrate. Plant Soil 304, 227-239.

Iavicoli, A., Boutet, E., Buchala, A., Métraux, J.-P., 2003. Induced systemic resistance in Arabidopsis thaliana in response to root inoculation with Pseudomonas fluorescens CHAO. Mol. Plant-Microbe Interact. 16, 851-858.

Jones, J.D.G., Dangl, J.L., 2006. The plant immune system. Nature 444, 323-329.

Kamilova, F., Lamers, G., Lugtenberg, B., 2008. Biocontrol strain Pseudomonas fluorescens WCS365 inhibits germination of Fusarium oxysporum spores in tomato root exudate as well as subsequent formation of new spores. Environ. Microbiol. 10, 2455-2461.

Kloepper, J.W., Ryu, C.M., Zhang, S.A., 2004. Induced systemic resistance and promotion of plant growth by Bacillus spp.. Phytopathology 94, 1259-1266.

Knoester, M., Pieterse, C.M.J., Bol, J.F., Van Loon, L.C., 1999. Systemic resistance in Arabidopsis induced by rhizobacteria requires ethylene-dependent signaling at the site of application. Mol. Plant-Microbe Interact. 12, 720-727.

Korolev, N., Rav David, D., Elad, Y., 2008. The role of phytohormones in basal resistance and Trichoderma-induced systemic resistance to Botrytis cinerea in Arabidopsis thaliana. Biocontrol 53, 667-683.

Leon-Reyes, A., Spoel, S.H., De Lange, E.S., Abe, H., Kobayashi, M., Tsuda, S., Millenaar, F.F., Welschen, R.A.M., Ritsema, T., Pieterse, C.M.J., 2009. Ethylene modulates the role of NPR1 in cross-talk between salicylate and jasmonate signaling. Plant Physiol. 149, 1797-1809.
Liu, J., Maldonado-Mendoza, I., Lopez-Meyer, M., Cheung, F., Town, C.D., Harrison, M. . 2007. Arbuscular mycorrhizal symbiosis is accompanied by local and systemic alterations in gene expression and an increase in disease resistance in the shoots. Plant J. 50, 529-544.

Loake, G., Grant, M., 2007. Salicylic acid in plant defence-the players and protagonists. Curr. Opin. Plant Biol. 10, 466-472.

Lorenzo, O., Piqueras, R., Sánchez-Serrano, J.J., Solano, R., 2003. Ethylene response factor 1 integrates signals from ethylene and jasmonate pathways in plant defense. Plant Cell 15, 165-178.

Lorenzo, O., Solano, R., 2005. Molecular players regulating the jasmonate signalling network. Curr. Opin. Plant Biol. 8, 532-540.

Lugtenberg, B.J.J., Dekkers, L., Bloemberg, G.V., 2001. Molecular determinants of rhizosphere colonization by Pseudomonas. Annu. Rev. Phytopathol. 39, 461-490.

Meziane, H., Van der Sluis, I., Van Loon, L.C., Höfte, M., Bakker, P.A.H.M., 2005. Determinants of Pseudomonas putida WCS358 involved in inducing systemic resistance in plants. Mol. Plant Pathol. 6, 177-185.

Miché, L., Battistoni, F., Gemmer, S., Belghazi, M., Reinhold-Hurek, B., 2006. Upregulation of jasmonate-inducible defense proteins and differential colonization of roots of Oryza sativa cultivars with the endophyte Azoarcus sp.. Mol. Plant-Microbe Interact. 19, 502-511.

Paparu, P., Dubois, T., Coyne, D., Viljoen, A., 2007. Defense-related gene expression in susceptible and tolerant bananas (Musa spp.) following inoculation with nonpathogenic Fusarium oxysporum endophytes and challenge with Radopholus similis. Physiol. Mol. Plant Pathol. 71, 149-157.

Pieterse, C.M.J., Dicke, M., 2007. Plant interactions with microbes and insects: from molecular mechanism to ecology. Trends Plant Sci. 12, 564-569.

Pieterse, C.M.J., Van Loon, L.C., 2004. NPR1: the spider in the web of induced resistance signaling pathways. Curr. Opin. Plant Biol. 7, 456-464.

Pieterse, C.M.J., Leon-Reyes, A., Van der Ent, S., Van Wees, S.C.M., 2009. Networking by small-molecule hormones in plant immunity. Nat. Chem. Biol. 5, 308-316.

Pieterse, C.M.J., Van Pelt, J.A., Ton, J., Parchmann, S., Mueller, M.J., Buchala, A.J., Métraux, J.-P., Van Loon, L.C., 2000. Rhizobacteria-mediated induced systemic resistance (ISR) in Arabidopsis requires sensitivity to jasmonate and ethylene but is not accompanied by an increase in their production. Physiol. Mol. Plant Pathol. 57, 123-134.

Pieterse, C.M.J., Van Wees, S.C.M., Hoffland, E., Van Pelt, J.A., Van Loon, L.C., 1996. Systemic resistance in Arabidopsis induced by biocontrol bacteria is independent of salicylic acid accumulation and pathogenesis-related gene expression. Plant Cell 8, 1225-1237.

Pieterse, C.M.J., Van Wees, S.C.M., Van Pelt, J.A., Knoester, M., Laan, R., Gerrits, H. Weisbeek, P.J., Van Loon, L.C., 1998. A novel signaling pathway controlling induced systemic resistance in Arabidopsis. Plant Cell 10, 1571-1580.

Pozo, M.J., Azcon-Aguilar, C., 2007. Unraveling mycorrhiza-induced resistance. Curr. Opin. Plant Biol. 10, 393-398.

Pozo, M.J., Van der Ent, S., Van Loon, L.C., Pieterse, C.M.J., 2008. Transcription factor MYC2 is involved in priming for enhanced defense during rhizobacteriainduced systemic resistance in Arabidopsis thaliana. New Phytol. 180, 511-523.

Pré, M., Atallah, M., Champion, A., De Vos, M., Pieterse, C.M.J., Memelink, J., 2008. The AP2/ERF domain transcription factor ORA59 integrates jasmonic acid and ethylene signals in plant defense. Plant Physiol. 147, 1347-1357.

Press, C.M., Wilson, M., Tuzun, S., Kloepper, J.W., 1997. Salicylic acid produced by Serratia marcescens $91-166$ is not the primary determinant of induced systemic resistance in cucumber or tobacco. Mol. Plant-Microbe Interact. 10, 761-768.

Raaijmakers, J.M., de Bruijn, I., de Kock, M.J.D., 2006. Cyclic lipopeptide production by plant-associated Pseudomonas spp.: diversity, activity, biosynthesis, and regulation. Mol. Plant-Microbe Interact. 19, 699-710.

Ross, A.F., 1961. Systemic acquired resistance induced by localized virus infections in plants. Virology $14,340-358$

Rudrappa, T., Czymmek, K.J., Pare, P.W., Bais, H.P., 2008. Root-secreted malic acid recruits beneficial soil bacteria. Plant Physiol. 148, 1547-1556.

Ryu, C.-M., Farag, M.A., Hu, C.H., Reddy, M.S., Kloepper, J.W., Paré, P.W., 2004a. Bacterial volatiles induce systemic resistance in Arabidopsis. Plant Physiol. 134, 1017-1026.

Ryu, C.-M., Hu, C.-H., Reddy, M.S., Kloepper, J.W., 2003. Different signaling pathways of induced resistance by rhizobacteria in Arabidopsis thaliana against two pathovars of Pseudomonas syringae. New Phytol. 160, 413-420.

Ryu, C.-M., Murphy, J.F., Mysore, K.S., Kloepper, J.W., 2004b. Plant growthpromoting rhizobacteria systemically protect Arabidopsis thaliana against Cucumber mosaic virus by a salicylic acid and NPR1-independent and jasmonic acid-dependent signaling pathway. Plant J. 39, 381-392.

Sanchez, L., Weidmann, S., Arnould, C., Bernard, A.R., Gianinazzi, S., GianinazziPearson, V., 2005. Pseudomonas fluorescens and Glomus mosseae trigger DMI3dependent activation of genes related to a signal transduction pathway in roots of Medicago truncatula. Plant Physiol. 139, 1065-1077.

Schwessinger, B., Zipfel, C., 2008. News from the frontline: recent insights into PAMP-triggered immunity in plants. Curr. Opin. Plant Biol. 11, 389-395.

Segarra, G., Van der Ent, S., Trillas, I., Pieterse, C.M.J., 2009. MYB72, a node of convergence in induced systemic resistance triggered by a fungal and a bacterial beneficial microbe. Plant Biol. 11, 90-96.

Shoresh, M., Yedidia, I., Chet, I., 2005. Involvement of jasmonic acid/ethylene signaling pathway in the systemic resistance induced in cucumber by Trichoderma asperellum T203. Phytopathology 95, 76-84.

Spaink, H.P., 2000. Root nodulation and infection factors produced by rhizobial bacteria. Annu. Rev. Microbiol. 54, 257-288.

Stein, E., Molitor, A., Kogel, K.-H., Waller, F., 2008. Systemic resistance in Arabidopsis conferred by the mycorrhizal fungus Piriformospora indica requires jasmonic 
acid signaling and the cytoplasmic function of NPR1. Plant Cell Physiol. 49, 1747-1751.

Tjamos, S.E., Flemetakis, E., Paplomatas, E.J., Katinakis, P., 2005. Induction of resistance to Verticillium dahliae in Arabidopsis thaliana by the biocontrol agent K-165 and pathogenesis-related proteins gene expression. Mol. Plant-Microbe Interact. 18, 555-561.

Ton, J., De Vos, M., Robben, C., Buchala, A., Métraux, J.-P., Van Loon, L.C., Pieterse, C.M.J., 2002a. Characterization of Arabidopsis enhanced disease susceptibility mutants that are affected in systemically induced resistance. Plant J. 29, 11-21.

Ton, J., Van Pelt, J.A., Van Loon, L.C., Pieterse, C.M.J., 2002b. Differential effectivenes of salicylate-dependent and jasmonate/ethylene-dependent induced resistance in Arabidopsis. Mol. Plant-Microbe Interact. 15, 27-34.

Tran, H., Ficke, A., Asiimwe, T., Höfte, M., Raaijmakers, J.M., 2007. Role of the cyclic lipopeptide massetolide A in biological control of Phytophthora infestans and in colonization of tomato plants by Pseudomonas fluorescens. New Phytol. 175 731-742.

Truman, W., Bennett, M.H., Kubigsteltig, I., Turnbull, C., Grant, M., 2007. Arabidopsis systemic immunity uses conserved defense signaling pathways and is mediated by jasmonates. Proc. Natl. Acad. Sci. USA 104, 1075-1080.

Van der Ent, S., Van Hulten, M.H.A., Pozo, M.J., Czechowski, T., Udvardi, M.K. Pieterse, C.M.J., Ton, J., 2009. Priming of plant innate immunity by rhizobacteria and $\beta$-aminobutyric acid: differences and similarities in regulation. New Phytol. $189,419-431$

Van der Ent, S., Verhagen, B.W.M., Van Doorn, R., Bakker, D., Verlaan, M.G., Pel, M.J.C., Joosten, R.G., Proveniers, M.C.G., Van Loon, L.C., Ton, J., Pieterse, C.M.J. 2008. MYB72 is required in early signaling steps of rhizobacteria-induced systemic resistance in Arabidopsis. Plant Physiol. 146, 1293-1304.

Van Hulten, M., Pelser, M., Van Loon, L.C., Pieterse, C.M.J., Ton, J., 2006. Costs and benefits of priming for defense in Arabidopsis. Proc. Natl. Acad. Sci. USA 103 $5602-5607$

Van Loon, L.C., Bakker, P.A.H.M., 2006. Root-associated bacteria inducing systemic resistance. In: Gnanamanickam, S.S. (Ed.), Plant-Associated Bacteria. Springer, Dordrecht, pp. 269-316.

Van Loon, L.C., Bakker, P.A.H.M., Pieterse, C.M.J., 1998. Systemic resistance induced by rhizosphere bacteria. Annu. Rev. Phytopathol. 36, 453-483.

Van Loon, L.C., Bakker, P.A.H.M., Van der Heijdt, W.H.W., Wendehenne, D., Pugin, A. 2008. Early responses of tobacco suspension cells to rhizobacterial elicitors of induced systemic resistance. Mol. Plant-Microbe Interact. 21, 1609-1621.

Van Loon, L.C., Rep, M., Pieterse, C.M.J., 2006. Significance of inducible defenserelated proteins in infected plants. Annu. Rev. Phytopathol. 44, 135-162.

Van Oosten, V.R., Bodenhausen, N., Reymond, P., Van Pelt, J.A., Van Loon, L.C., Dicke M., Pieterse, C.M.J., 2008. Differential effectiveness of microbially induced resistance against herbivorous insects in Arabidopsis. Mol. Plant-Microbe Interact. 21, 919-930.

Van Wees, S.C.M., De Swart, E.A.M., Van Pelt, J.A., Van Loon, L.C., Pieterse, C.M.J., 2000. Enhancement of induced disease resistance by simultaneous activation of salicylate- and jasmonate-dependent defense pathways in Arabidopsis thaliana Proc. Natl. Acad. Sci. USA 97, 8711-8716.

Van Wees, S.C.M., Luijendijk, M., Smoorenburg, I., Van Loon, L.C., Pieterse, C.M.J., 1999. Rhizobacteria-mediated induced systemic resistance (ISR) in Arabidopsis is not associated with a direct effect on expression of known defense-related genes but stimulates the expression of the jasmonate-inducible gene Atvsp upon challenge. Plant Mol. Biol. 41, 537-549.

Van Wees, S.C.M., Pieterse, C.M.J., Trijssenaar, A., Van 't Westende, Y.A.M., Hartog, F., Van Loon, L.C., 1997. Differential induction of systemic resistance in Arabidopsis by biocontrol bacteria. Mol. Plant-Microbe Interact. 10, 716-724.

Van Wees, S.C.M., Van der Ent, S., Pieterse, C.M.J., 2008. Plant immune responses triggered by beneficial microbes. Curr. Opin. Plant Biol. 11, 443-448.

Verberne, M.C., Hoekstra, J., Bol, J.F., Linthorst, H.J.M., 2003. Signaling of systemic acquired resistance in tobacco depends on ethylene perception. Plant J. 35, 27 32

Verhagen, B.W.M., Glazebrook, J., Zhu, T., Chang, H.-S., Van Loon, L.C., Pieterse, C.M. 2004. The transcriptome of rhizobacteria-induced systemic resistance in Arabidopsis. Mol. Plant-Microbe Interact. 17, 895-908.

Vinale, F., Sivasithamparam, K., Ghisalberti, E.L., Marra, R., Woo, S.L., Lorito, M. 2008. Trichoderma-plant-pathogen interactions. Soil Biol. Biochem. 40, 1-10.

Vlot, A.C., Klessig, D.F., Park, S.-W., 2008. Systemic acquired resistance: the elusive signal(s). Curr. Opin. Plant Biol. 11, 436-442.

Walker, T.S., Bais, H.P., Halligan, K.M., Stermitz, F.R., Vivanco, J.R., 2003. Metabolic profiling of root exudates of Arabidopsis thaliana. J. Agric. Food Chem. 51, 2548 2554.

Waller, F., Achatz, B., Baltruschat, H., Fodor, J., Becker, K., Fischer, M., Heier, T. Huckelhoven, R. Neumann, C. von Wettstein, D. Franken, P., Kogel, K.H. 2005. The endophytic fungus Piriformospora indica reprograms barley to salt-stress tolerance, disease resistance, and higher yield. Proc. Natl. Acad. Sci. USA 102 13386-13391.

Waller, F., Mukherjee, K., Deshmukh, S.D., Achatz, B., Sharma, M., Schaefer, P., Kogel, K.H., 2008. Systemic and local modulation of plant responses by Piriformospora indica and related Sebacinales species. J. Plant Physiol. 165, 60-70.
Walters, D., Heil, M., 2007. Costs and trade-offs associated with induced resistance. Physiol. Mol. Plant Pathol. 71, 3-17.

Walters, D.R., Boyle, C., 2005. Induced resistance and allocation costs: what is the impact of pathogen challenge? Physiol. Mol. Plant Pathol. 66, 40-44.

Walters, D.R., Paterson, L., Walsh, D.J., Havis, N.D., 2009. Priming for plant defense in barley provides benefits only under high disease pressure. Physiol. Mol. Plant Pathol. doi:10.1016/j.pmpp.2009.03.002.

Wang, Y.Q., Ohara, Y., Nakayashiki, H., Tosa, Y., Mayama, S., 2005. Microarray analysis of the gene expression profile induced by the endophytic plant growthpromoting rhizobacteria, Pseudomonas fluorescens FPT9601-T5 in Arabidopsis. Mol. Plant-Microbe Interact. 18, 385-396.

Weller, D.M., Raaijmakers, J.M., McSpadden Gardener, B.B., Thomashow, L.S., 2002 Microbial populations responsible for specific soil suppressiveness to pathogens. Annu. Rev. Phytopathol. 40, 309-348.

Yan, Z., Reddy, M.S., Ryu, C.-M., McInroy, J.A., Wilson, M., Kloepper, J.W., 2002 Induced systemic protection against tomato late blight elicited by plant growth-promoting rhizobacteria. Phytopathology 92, 1329-1333.

Yang, J., Kloepper, J.W., Ryu, C.-M., 2009. Rhizosphere bacteria help plants tolerate abiotic stress. Trends Plant Sci. 14, 1-4.

Zehnder, G.W., Murphy, J.F., Sikora, E.J., Kloepper, J.W., 2001. Application of rhizobacteria for induced resistance. Eur. J. Plant Pathol. 107, 39-50.

Zhang, H., Xie, X., Kim, M.-S., Kornyeyev, D.A., Holaday, S., Paré, P.W., 2008. Soil bacteria augment Arabidopsis photosynthesis by decreasing glucose sensing and abscisic acid levels in planta. Plant J. 56, 264-273.

Zhang S., Moyne, A.-L., Reddy, M.S., Kloepper, J.W. 2002. The role of salicylic acid in induced systemic resistance elicited by plant growth-promoting rhizobacteria against blue mold of tobacco. Biol. Control 25, 288-296.

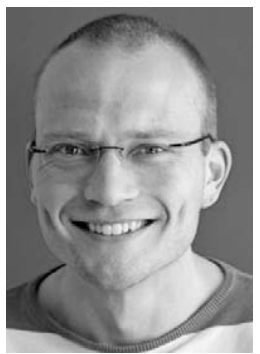

Sjoerd van der Ent performed his PhD research at the Utrecht University on the role of transcription factors in the regulation of rhizobacteria-mediated induced systemic resistance (ISR) in Arabidopsis thaliana. He was able to gain novel insights into the molecular mechanisms underlying the phenomenon of priming for enhanced defense, which emerged as an important mechanism associated with induced resistance that is triggered by beneficial microbes. After his graduation in 2008, he continued his research as a postdoctoral fellow in the Plant-Microbe Interactions group at the Department of Biology, Utrecht University.

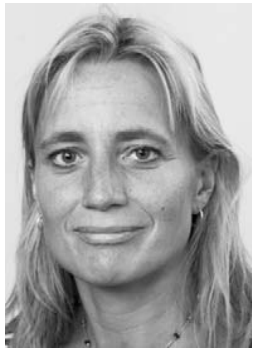

Saskia van Wees obtained her PhD degree in 1999 at the Utrecht University where she performed pioneering work on signaling during rhizobacteria-mediated induced systemic resistance (ISR) in Arabidopsis thaliana. After her graduation she moved to the Torrey Mes Research Institute, San Diego, USA where she worked as a postdoctoral fellow in the laboratory of Jane Glazebrook on mechanisms of disease resistance against necrotrophic fungi. In 2004, she received a VENI fellowship from the Netherlands Science Foundation to study the role of phospholipids in plant defense at the University of Amsterdam in the laboratory of Teun Munnik. In 2007, she moved back to her roots at the Utrecht University where she now works as a senior scientist in the Plant-Microbe Interactions laboratory.

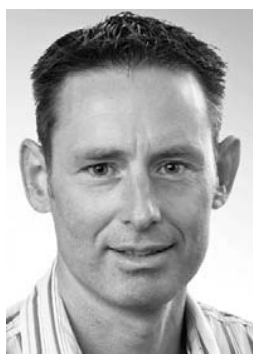

Corné Pieterse was educated at the Wageningen University where he studied Plant Breeding and perfomed his $\mathrm{PhD}$ research at the laboratory of Phytopathology on differential gene expression in Phytophthora infestan during pathogenesis on potato. After receiving his $\mathrm{PhD}$ degree in 1993, he moved to the Phytopathology laboratory at the Utrecht University to work on the molecular mechanisms underlying rhizobacteria-mediated ISR in Arabidopsis thaliana. In 2004, he was awarded a VICI innovational research fellowship from the Netherlands Science Foundation for his research on cross-talk between plant defense signaling pathways. Since 2004 he is Professor in Plant-Microbe Interactions at the Department of Biology, Utrecht University. His research group explores Arabidopsis thaliana to investigate the plant immune system and to understand how plants are able to defend themselves against pathogen and insect attack. 